\title{
MODELING MASS-BALANCE CHANGES DURING A GLACIATION CYCLE
}

\author{
by \\ M.S. Pelto, \\ (Nichols College, Dudley, MA 01570, U.S.A.) \\ S.M. Higgins, T.J. Hughes, and J.L. Fastook \\ (Institute for Quaternary Studies, University of Maine, Orono, ME 04469, U.S.A.)
}

\section{ABSTRACT}

Identification of present-day climate setting and alpine glacier-balance gradients indicates that the balance gradient of alpine glaciers is primarily determined by climatic conditions. Determination of balance gradients for specific climatic settings on present-day ice sheets provides an analog for determining the mass balance on paleo and future ice sheets.

\section{INTRODUCTION}

Mass balance is a primary variable determining the size, height, and shape of ice sheets. One of the fundamental inputs to ice-sheet models is surface mass balance. In order to construct or reconstruct ice sheets the temporal and spatial variation of mass balance must be known. The surface mass balance on an ice sheet is determined by climatic conditions. To determine the mass balance at a given point requires knowing the climatic conditions and elevation of that point. This paper describes a method for determining the temporal and spatial variations of mass balance for ice-sheet reconstructions. Unfortunately, there is no satisfactory equation relating mass balance to specific climate variables. It is equally impossible to specifically determine the climate conditions for the past and the future. However, GCMs and proxy climate records do allow the general climate setting to be identified. Climate settings represent a range of climatic conditions.

Reconstructions of ice sheets have typically relied on mass-balance models based either on mass-balance distribution over the Antarctic ice sheet or Greenland ice sheet, or on the present distribution of precipitation adjusted for ice-age conditions. In reality, the balance gradient of an ice sheet is determined by climate. Thus, climatic setting should be used for reconstructing ice-sheet mass-balance patterns.

\section{BALANCE GRADIENT CONSTRUCTION}

The balance gradient of a glacier is the change in balance with altitude. Published balance gradients (Table I) for present-day alpine glaciers, where the climate setting is known, cluster into five distinct populations. Cluster analysis indicates that $81 \%$ of the alpine glaciers can be accurately assigned to one of the five populations. The five climate settings were chosen to provide the best fit to the data. Each of the five populations is a distinct climatic regime: (1) temperate maritime, (2) sub-polar maritime, (3) subpolar mix, (4) polar mix, (5) polar continental (Fig. 1). In addition, a polar desert climatic zone exists over the interior of Antarctica. Each climate zone is typified by temperatures ranging from temperate to polar and by precipitation ranging from maritime to continental (Table II). The sub-polar mix and polar mix climate zones are distinguished by E.LA more than by a balance-gradient change. The fact that alpine glacier balance gradients are grouped climatically

TABLE I. BALANCE GRADIENT $(B(n))$ OF SELECTED ALPINE GLACIERS. BALANCE GRADIENTS ARE REPORTED IN $\mathrm{cm} 100 \mathrm{~m}^{-1}$. CLIMATE SETTING, LATITUDE AND REFERENCE FOR THE BALANCEGRADIENT INFORMATION ARE ALSO LISTED

No. Glacier

1 Taku

2 Lemon

3 Berendon

4 Columbia

5 Malaspina

6

7$$
9
$$

Storbreen

Hamberg

Hodges

Nisqually

Blue

Rainbow

Lynch

Sentinel

Narssaq

\section{Mendenhall}

Wolverine

Vatnajökull

Nigardsbreen

Engabreen

Ảlfotbreen

Trollsbergdalsbreen

Høgtvubreen

Hardangerjökull

Austre Memurubre

Hoffellsjökull

Bondhusbreen

Folgefonni

Tunsbergdalsbreen

South Cascade

Columbia

Vestfonna

Frøyabreen

Fjortende Julibreen PX

Qamanârssûp sermia PX

Valhaltindegletscher PX

Hellstugubreen

Zone $B(n)$ Lat. References

$\begin{array}{cccl}\text { SM } & 87 & 58 & \text { Mayo, 1984 } \\ \text { SM } & 120 & 58 & \text { Mayo, 1984 } \\ \text { SM } & 90 & 56 & \text { Mayo, 1984 } \\ \text { SM } & 94 & 61 & \text { Mayo, 1984 } \\ \text { SM } & 85 & 60 & \text { Mayo, 1984 } \\ & & & \\ \text { SM } & 80 & 58 & \text { Pelto, 1987 } \\ \text { SM } & 105 & 63 & \text { Mayo, 1984 } \\ \text { SM } & 80 & 64 & \text { Ahlmann, 194 } \\ \text { SM } & 97 & 61 & \text { Schytt, 1969 } \\ \text { SM } & 83 & 67 & \text { Schytt, 1969 } \\ \text { SM } & 100 & 61 & \text { Schytt, 1969 } \\ \text { SM } & 88 & 61 & \text { Schytt, 1969 } \\ \text { SM } & 75 & 54 & \text { Smith, 1960 } \\ & & & \\ \text { SM } & 90 & 54 & \text { Smith, 1960 } \\ \text { SM } & 68 & 66 & \text { Østrem and o }\end{array}$

1979

SM 8066 Østrem and others, 1979

SM 7860 Østrem and others, 1979

SM 7362 Østrem and others, 1979

SM $75 \quad 67$ Ahlmann, 1948

SM $80 \quad 60$ Østrem and others, 1979

SM 10060 Østrem and others, 1979

SM 7066 Østrem and others, 1979

TM $150 \quad 48 \quad$ Mayo, 1984

TM $145 \quad 49$ Mayo, 1984

TM $120 \quad 49$ Mayo, 1984

TM $110 \quad 49$ Pelto, 1988

TM $160 \quad 48$ Pelto, 1988

TM $\quad 160 \quad 48$ Pelto, 1988

Austfonna

Vøringbreen

Bogerbreen
PX $42 \quad 79 \quad$ Schytt, 1964

TM $\quad 120 \quad 51 \quad$ Braithwaite, 1984

PX $40 \quad 79$ Schytt, 1964

PX $\quad 45 \quad 74$ Ahlmann, 1948

$\begin{array}{llll} & 43 & 64 & \text { Braithwaite, } 1986\end{array}$

61 Weidick, 1984

61 Weidick, 1984 1969

PX $45 \quad 78$ Guskov and

Troitskiy, 1984

PX $\quad 36 \quad 78$ Guskov and

Troitskiy, 1984 
Graph of Iable 1: Balance Gradients Ys Latitudes

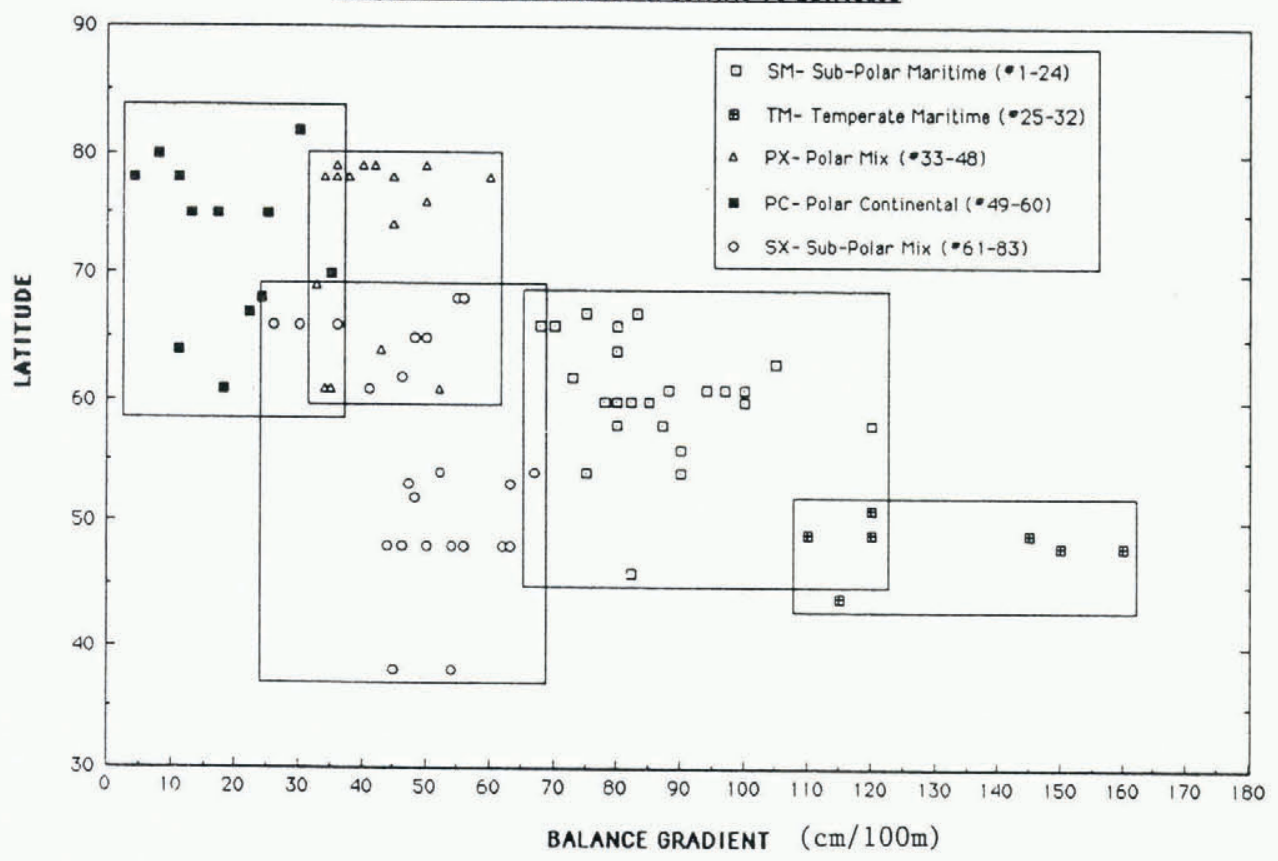

No. Glacier

44 Longyearbreen

45 Daudbreen

46 Bertilbreen

47 Laika Ice Cap

48 Lilliehöökbreen

49 Nunatarssuaq

50 Baby

51 Devon

2 Decade

McCall

Hazen

Taylor

Barnes

Penny

White

Gråsubreen

James Ross Island

Sonneblickes

Vernagtferner

Kesselwandferner

Hintereisferner

Caréser

Silveretta

Malaiy

Peyto

Place

Woolsey

Ram River

Saskatchewan

Storglaciären

Tuyuksu

Blảisen

77 Cainhavarre

Zone $B(n)$ Lat. References

PX $34 \quad 78$ Guskov and

Troitskiy, 1984

$\begin{array}{llll}\text { PX } & 38 & 78 & \text { Guskov and }\end{array}$

Troitskiy, 1984

PX $\quad \begin{array}{lll}60 & 78 & \text { Guskov and }\end{array}$

Troiskiy, 1984

PX $50 \quad 76$ Blatter and

Kappenberger, 1988

PX $50 \quad 79$ Ahlmann, 1939

PC $25 \quad 75$ Weidick, 1984

PC $\quad 30 \quad 82 \quad$ Braithwaite, 1984

PC $\quad 8 \quad 80 \quad$ Braithwaite, 1984

PC $\quad 11 \quad 78$ Braithwaite, 1984

PC $24 \quad 68$ Mayo, 1984

$\begin{array}{lll}\text { PC } & 17 & 25\end{array}$

$\begin{array}{llll}P C & 4 & 78 & \text { Robinson, } 1984\end{array}$

PC $35 \quad 70$ Baird, 1952

PC $22 \quad 67$ Koerner, 1979

PC $13 \quad 75$ Braithwaite, 1984

PC $18 \quad 61$ Schytt, 1967

PC $11 \quad 64$ Aristarain and others, 1987

SX $44 \quad 48$ Braithwaite, 1984

SX $\quad 56 \quad 48 \quad$ Braithwaite, 1984

SX $\quad 63 \quad 48 \quad$ Braithwaite, 1984

SX $\quad 50 \quad 48$ Braithwaite, 1984

SX $\quad 62 \quad 48$ Braithwaite, 1984

SX $\quad 54 \quad 48$ Braithwaite, 1984

SX $45 \quad 38$ Dyugerov and others, 1988

SX $\quad 52 \quad 54 \quad$ Braithwaite, 1984

SX $477 \quad 53 \quad$ Braithwaite, 1984

SX $48 \quad 52$ Braithwaite, 1984

$\begin{array}{llll}\text { SX } & 63 & 53 & \text { Braithwaite, } 1984\end{array}$

SX $\quad \begin{array}{llll}67 & 54 & \text { Braithwaite, } 1984\end{array}$

SX $\quad 55 \quad 68$ Braithwaite, 1984

SX $\quad 54 \quad 38 \quad$ Braithwaite, 1984

SX $36 \quad 66$ Østrem and Pytte, 1969

SX 3066 Østrem and Pytte, 1969

Storsteinsf jellbreen SX

BALANCE GRADIENT （cm/100m)

Fig. 1. Balance gradient of alpine glaciers versus latitude. Balance gradient is in $\mathrm{cm} 100 \mathrm{~m}^{-1}$; this is a standard unit of reporting.

\section{TABLE II. CLIMATIC CONDITIONS ASSOCIATED WITH} EACH OF THE FIVE CLIMATE SETTINGS

$\begin{array}{lccc}\text { Climate zone } & \begin{array}{c}\text { Winter } \\ \text { temperature } \\ \text { ' }\end{array} & \begin{array}{c}\text { Summer } \\ \text { temperature }\end{array} & \begin{array}{c}\text { Annual } \\ \text { precipitation }\end{array} \\ \text { Polar continental } & <-20 & <\mathrm{C} & \mathrm{m} \\ \text { Polar mix } & <-15 & <6 & <0.4 \\ \text { Sub-polar mix } & -10 \text { to }-15 & 8-12 & 0.4-1.0 \\ \text { Sub-polar maritime } & -6 \text { to }-12 & 6-10 & 0.6-1.2 \\ \text { Temperate maritime } & 0 \text { to }-6 & 10-16 & >1.2 \\ & & & >1.5\end{array}$

indicates that the balance gradient is determined by its climate setting (Schytt, 1967). Hence, if the climatic setting can be identified, then the mean balance gradient of local alpine glaciers can be determined.

The climate setting is determined at the margin of the glacier. This method was used for two reasons: (1) this is where most weather records and proxy climate data exist. (2) mass-balance distribution on present-day glaciers is determined by the regional climate setting, which reflects the regional air masses. The air masses are modified by the ice sheet. For this reason, above $2400 \mathrm{~m}$ all of the balance curves approach a polar continental climate setting. Below $2400 \mathrm{~m}$, the climate setting at the margin determines the balance gradient. Above $2400 \mathrm{~m}$, the climate setting over ice sheets is polar continental.

TABLE III. SOURCES FOR MASS-BALANCE VERSUS ELEVATION DATA USED TO FIT THE BALANCE GRADIENTS FOR EACH CLIMATE ZONE

Climate Data sources

zone

PC Baird, 1952; Benson, 1962; Koerner, 1979; 1969 PC

Giovinetto and Bentley, 1985; Aristarain and others, 1987; Blatter and Kappenberger, 1988

PX Ahlmann, 1939, 1948; Schytt, 1964; Weidick, 1984; Braithwaite, 1986; Kostecka and Whillans, 1988

SX Benson, 1962; Weidick, 1984; Braithwaite, 1986

SM Ahlmann, 1939, 1948; Smith, 1960

TM Ahlmann, 1939; Mayo, 1984; Pelto, 1987 


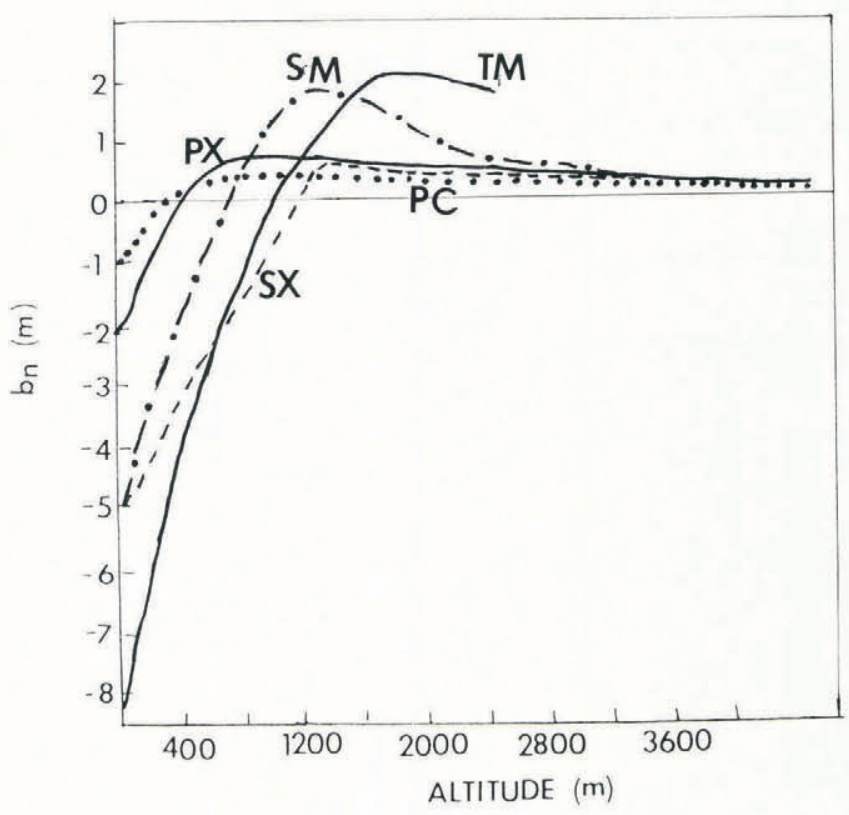

Fig. 2. The balance curve obtained by application of Equation (1) to available ice-sheet and ice-cap mass-balance data.

Mass-balance variations within a climate zone are determined primarily by elevation. Thus a mass-balance equation must be able to calculate mass balance from elevation. Data of mass-balance changes with elevation from ice caps and ice sheets in each of the five climate zones are used to reconstruct a mean balance gradient for that zone. Data sources are indicated in Table III. Data are not used from alpine glaciers because of the steep slopes that cause large fluctuations in orographic precipitation and hence mass balance. A least-squares fit is used to obtain the most representative balance gradient for the cloud of data points from each climate zone. It is not necessary to use least squares to obtain a good fit, but least squares did provide the best fit. Equation (1) is used to obtain best-fit balance gradients:

$$
A(h)=A_{1} \mathrm{e}^{-x_{1} h^{2}}+A_{2} \mathrm{e}^{-x_{2} h^{2}}
$$

where $h(\mathrm{~m})$ is the altitude of the previous time step, $A_{1}(\mathrm{~m})$ is ablation at the margin, $A_{2}(\mathrm{~m})$ is accumulation at the margin, $x_{1} \mathrm{~m} \mathrm{~m}^{-1}$ is the decay exponent of ablation with elevation, and $x_{2} \mathrm{~m} \mathrm{~m}^{-1}$ is the decay exponent of accumulation with elevation.

The constants obtained for each climate zone are shown in Table IV and the balance gradients in Figure 2. Figure 3 shows the balance gradient for polar continental conditions, and the data points used. In constructing ice sheets at a given time step, the elevation of the ice sheet is known at the previous time step. At the first time step the elevation is the bedrock elevation.

Distance from the margin, though an important massbalance parameter, is secondary to the effect of elevation.

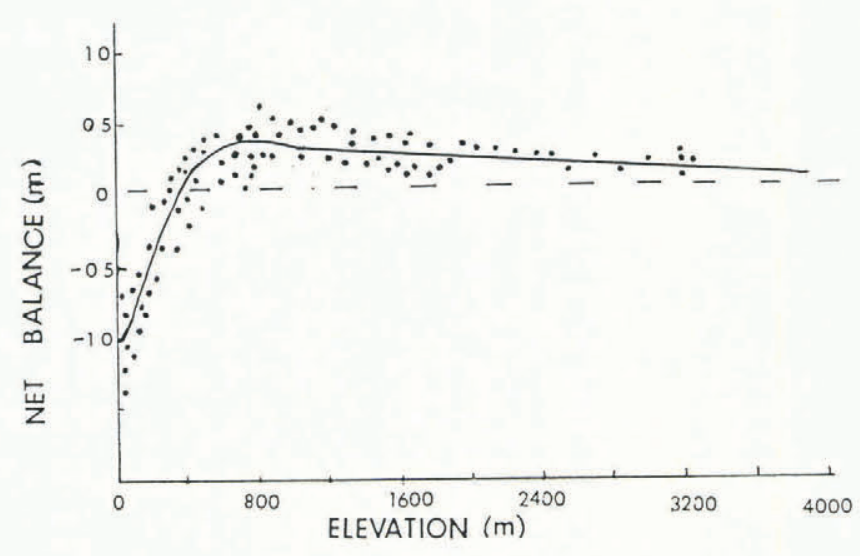

Fig. 3. The balance curve for the polar continental climate setting, with data points indicated. Dashed lines are the equilibrium lines.

The distance of importance is the distance to the primary moisture source measured along the transport path. This distance is seldom known. Thus, although distance from the margin influences mass balance, it cannot be included in the time-dependent finite element, because accurate determination for paleo or future ice sheets is not possible. Even attempting to utilize this parameter in duplicating present-day Antarctic mass balance has proven problematic. On ice sheets the elevation is strongly related to the distance from the edge of the ice sheet. Because the iceelevation term is squared in Equation (1) the distance from the ice-sheet margin though not directly included is implictly included in Equation (1).

The mass balance of an ice sheet during a glaciation cycle varies depending on the climatic setting. In particular the climatic setting below the ELA changes. The majority of the accumulation zone remains either in a polar continental or a polar desert climate zone. Ice sheets are most susceptible to changes in ablation because the ranges in ablation values are several times larger than for changes in accumulation (Ahlmann, 1948; Schytt, 1967; Weidick, 1984). An example is Jakobshavns Isbræ, where peak accumulation is $0.6 \mathrm{~m} \mathrm{a}^{-1}$ and ablation at the margin is $6.0 \mathrm{~m} \mathrm{a}^{-1}$. Peak ablation is an order of magnitude larger than peak accumulation, and the annual variation of ablation is an order of magnitude larger. This is especially true with respect to ice thickness near the margin. Hence, accurate ice-sheet reconstruction requires knowing the climatic setting in the ablation zone.

Mass-balance changes with time are caused primarily by changes in climatic setting. However, mass balance does change within climate zones, due to changes in the surface heat budget, caused by changes in atmospheric composition, changes in albedo, and changes of incoming solar insolation. The resulting changes in the balance gradient are represented by changes in ELA for each balance gradient. The shape of the balance gradient does not change, only the ELA shifts. That this is actually what happens is demonstrated by changes in climate such as the Little Ice Age. During the Little Ice Age climate zones did not change but ELA were reduced by $150-250 \mathrm{~m}$ (Denton and Karlén, 1975).

TABLE IV. THE CONSTANTS USED IN EQUATION (1) TO CONSTRUCT THE BALANCE GRADIENT FOR EACH CLIMATE ZONE. $A_{1}$ AND $A_{2}$ ARE THE ABLATION AND ACCUMULATION AT THE MARGIN, RESPECTIVELY. $X_{1}$ AND $X_{2}$ DETERMINE THE CHANGES IN ABLATION AND ACCUMULATION WITH ELEVATION

$\begin{array}{lccccr}\begin{array}{l}\text { Climate } \\ \text { zone }\end{array} & A_{1} & A_{2} & X_{1} & X_{2} & \text { ELA } \\ & \mathrm{m} & \mathrm{m} & \mathrm{m} \mathrm{m}^{-1} & \mathrm{~m} \mathrm{~m}^{-1} & \mathrm{~m} \\ \text { PC } & -1.2936 & 0.2998 & 1.5023 \times 10^{-6} & 3.6194 \times 10^{-8} & 312 \\ \text { PX } & -2.8490 & 0.8378 & 8.5345 \times 10^{-6} & 3.0453 \times 10^{-8} & 379 \\ \text { SM } & -7.5768 & 2.5689 & 2.7733 \times 10^{-6} & 2.9162 \times 10^{-7} & 660 \\ \text { SX } & -5.8563 & 0.8575 & 1.3228 \times 10^{-6} & 9.4618 \times 10^{-8} & 1250 \\ \text { TM } & -11.6877 & 3.67407 & 1.0838 \times 10^{-6} & 3.6411 \times 10^{-8} & 1050\end{array}$


The above method is fully quantitative and is based solely on all available data. With this method the massbalance distribution can be calculated once the climate setting is determined from proxy records and GCM results. The climate settings and balance gradients used are not ideal; however, they do produce good results based upon all currently available data. The main weakness of this method is in the dome regions, where climate and mass-balance relationships are poorly known.

\section{REFERENCES}

Ahlmann, H.W. 1948. Glaciological research on the North Atlantic coasts. London, Royal Geographical Society. (R.G.S. Research Series 1.)

Ahlmann, H.W. and S. Thorarinsson. 1939. Vatnajökull. Scientific results of the Swedish-Icelandic investigations 1936-37-38. Chapter VI. The accumulation. Geogr. Ann., 21(1), 39-66.

Aristarain, A.J., J.F. Pinglot, and M. Pourchet. 1987. Accumulation and temperature measurements on the James Ross Island ice cap, Antarctic Peninsula, Antarctica. $J$ Glaciol., 33(115), 357-362.

Baird, P.D. 1952. The glaciological studies of the Baffin Island expedition, 1950. Part 1: Method of nourishment of the Barnes Ice Cap. J. Glaciol., 2(11), 2-9.

Benson, C.S. 1962. Stratigraphic studies in the snow and firn of the Greenland ice sheet. CRREL Rep. 70.

Blatter, H. and G. Kappenberger. 1988. Mass balance and thermal regime of Laika ice cap, Coburg Island, N.W.T., Canada. J. Glaciol., 34(116), 102-110.

Braithwaite, R.J. 1984. Can the mass balance of a glacier be estimated from its equilibrium-line altitude? $J$. Glaciol., 30(106), 364-368.

Braithwaite, R.J. 1986. Assessment of mass-balance variations within a sparse stake network, Qamanârssûp sermia, West Greenland. J. Glaciol., 32(110), 50-53.

Denton, G.H. and W. Karlen. 1973. Holocene climatic variations - their pattern and possible cause. Quat. Res. 3(2), 155-205.

Dyurgerov, M.B., M.G. Kunakhovich, I.F. Khmelevskoy, and Yu.B. Shurdumov. 1988. Osobennosti vneshnego massoobmena Lednika Malyy Azau na El'bruse [Peculiarities of the external mass balance of Malyy and Azau glaciers, the El'brus]. Mater. Glyatsiol. Issled. 61, 91-95.
Giovinetto, M.B. and C. Bull. 1987. Summary and analysis of surface mass balance compilations for Antarctica 19601985. Ohio State University. Byrd Polar Research Center. Report 1

Gus'kov, A.S. and L.S. Troitskiy. 1984. Vodno-ledovyy balanslednikov Shpitsbergena v 1980/81 i 1981/82 balansovykh godakh [Water-ice balance of Spitsbergen glaciers in the 1980/81 and 1981/82 balance years] Mater. Glyatsiol. Issled. 51, 247-250.

Koerner, R.M. 1979. Accumulation, ablation, and oxygen isotope variations on the Queen Elizabeth Islands ice caps, Canada. J. Glaciol., 22(86), 25-41.

Kostecka, J.M. and I.M. Whillans. 1988. Mass balance along two transects of the west side of the Greenland ice sheet. J. Glaciol., 34(116), 31-39.

Mayo, L.R. 1984. Glacier mass balance and runoff research in the U.S.A. Geogr. Ann., 66A(3), 215-227.

Østrem, G., B. Wold, and K. Repp. 1979. Glasiologiske undersökelser $i$ Norge 1978. Oslo, Norges Vassdrags-og Elektrisitetsvesen.

Østrem, G. and R. Pytte. 1969. Glasiologiske undersökelser $i$ Norge 1968. Oslo, Norges Vassdrags-og Elektrisitetsvesen.

Pelto, M.S. 1987. Mass balance of south-east Alaska and north-west British Columbia glaciers from 1976 to 1984: methods and results. Ann. Glaciol., 9, 189-194.

Pelto, M.S. 1988. The annual balance of North Cascade glaciers, Washington, U.S.A., measured and predicted using an activity index method. J. Glaciol., 34(117), 194-199.

Pelto, M.S., T.J. Hughes, and H.H. Brecher. 1989. Equilibrium state of the Jakobshavns Isbræ, West Greenland. Ann. Glaciol., 12, 127-131.

Robinson, P.H. 1984. Ice dynamics and thermal regime of Taylor Glacier, south Victoria Land, Antarctica. $J$. Glaciol., 30(105), 155-160.

Schytt, V. 1964. Scientific results of the Swedish glaciological expedition to Nordaustlandet, Spitsbergen, 1957 and 1958. Geogr. Ann., 46(3), 243-281.

Schytt, V. 1967. A study of "ablation gradient". Geogr. Ann., 49A(2-4), 327-332.

Smith, J. 1960. Glacier problems in South Georgia. J. Glaciol., 3(28), 707-714.

Weidick, A. 1984. Studies of glacier behaviour and glacier mass balance in Greenland - a review. Geogr. Ann., 66A(3), 183-195. 